\section{Synthesis of the First Cluster Complexes Bearing Three Quadruply Bridging CO Ligands: X-ray Crystal Structure of $\left[\mathrm{C}_{5} \mathrm{H}_{3}\left(\mathrm{SiMe}_{3}\right)_{2}\right] \mathrm{WRu} \mathrm{u}_{6}\left(\mu_{3}-\mathrm{H}\right)$ - $(\mathrm{CO})_{18}$}

Yun Chi, ${ }^{*}, \dagger$ Chi-Jung Su, ${ }^{\dagger}$ Shie-Ming Peng, $, *, \star$ and Gene-Hsiang Lee

\section{Department of Chemistry, National Tsing Hua University Hsinchu 30043, Taiwan, Republic of China Department of Chemistry and Instrumentation Center National Taiwan University, Taipei 10764 Taiwan, Republic of China}

Received June 24, 1997

The transformation from a regular C-bonded, terminal, or bridging $\mathrm{CO}$ ligand to a quadruply bridging $\mathrm{CO}$ ligand is recognized as an essential requirement for the cleavage of the $\mathrm{C}-\mathrm{O}$ bond in metal cluster compounds and on metal surfaces. ${ }^{1}$ One of the interesting developments of recent years has been the realization that the tetrametallic butterfly clusters, such as $\left[\mathrm{Fe}_{4}(\mu-\mathrm{H})(\mathrm{CO})_{13}\right]^{-}$or $\mathrm{LMRu}_{3}(\mu-\mathrm{H})(\mathrm{CO})_{12}(\mathrm{M}=\mathrm{W}$ and $\mathrm{Mo} ; \mathrm{L}$ $=\mathrm{Cp}$ and $\left.\mathrm{C}_{5} \mathrm{Me}_{5}\right)$, bearing one quadruply bridging $\mathrm{CO}$ ligand, are able to undergo equilibration in solution with the tetrahedral isomers possessing only the regular terminal or bridging $\mathrm{CO}$ ligands. ${ }^{2,3}$ Thus, these isomerization studies provide explicit evidence for the rapid exchange between these two different types of CO ligands. Recently, this chemistry has been extended into the preparation of complexes possessing two $\mu_{4}$-CO ligands, as reported in the case of $\mathrm{Ru}_{6}$ cluster chemistry ${ }^{4}$ and its heterometallic domain. ${ }^{5}$ In the meantime, reactivity studies have demonstrated that these multisite-bound $\mathrm{CO}$ ligands can convert into carbide ligands through cleavage of $\mathrm{C}-\mathrm{O}$ bond. ${ }^{6}$ In this communication, we extend the scope of these investigations, and report the first synthesis of $\mathrm{WRu}_{6}$ compounds bearing three such uncommon $\mu_{4}-\mathrm{CO}$ ligands and a related cluster compound with two $\mu_{4}$-CO ligands, generated from direct hydrogenation.

The hydride complex $\left[\mathrm{C}_{5} \mathrm{H}_{3}\left(\mathrm{SiMe}_{3}\right)_{2}\right] \mathrm{W}(\mathrm{CO})_{3} \mathrm{H}$, synthesized from $\mathrm{C}_{5} \mathrm{H}_{4}\left(\mathrm{SiMe}_{3}\right)_{2}$ and $\mathrm{W}(\mathrm{CO})_{3}(\mathrm{NCEt})_{3}$, was added into a toluene solution of $\mathrm{Ru}_{3}(\mathrm{CO})_{12}$ at reflux over a period of $3 \mathrm{~h}$. Workup of the reaction mixture by routine TLC gave a $\mathrm{WRu}_{6}$ complex $\left[\mathrm{C}_{5} \mathrm{H}_{3}\left(\mathrm{SiMe}_{3}\right)_{2}\right] \mathrm{WRu}_{6}\left(\mu_{3}-\mathrm{H}\right)(\mathrm{CO})_{18}(\mathbf{1 a})$ in $28 \%$ yield. ${ }^{7}$ The analogous $\mathrm{C}_{5} \mathrm{H}_{4}\left(\mathrm{SiMe}_{3}\right)$ and $\mathrm{C}_{5} \mathrm{H}_{4}\left(\mathrm{CHMe}_{2}\right)$ substituted

\footnotetext{
$\dagger$ National Tsing Hua University.
}

\$ational Taiwan University.

(1) (a) Horwitz, C. P.; Shriver, D. F. Adv. Organomet. Chem. 1984, 23, 219. (b) Ichikawa, M.; Lang, A. J.; Shriver, D. F.; Sachtler, W. M. H. J. Am. Chem. Soc. 1985, 107, 7216. (c) Blyholder, G.; Lawless, M. J. Chem. Soc., Chem. Commun. 1990, 632. (d) Chisholm, M. L.; Hammond, C. E.; Johnston, V. J.; Streib, W. E.; Huffman, J. C. J. Am. Chem. Soc. 1992, $114,7056$.

(2) (a) Manassero, M.; Sansoni, M.; Longoni, G. J. Chem. Soc., Chem. Commun. 1976, 919. (b) Horwitz, C. P.; Shriver, D. F. Organometallics 1984, 3, 756. (c) Horwitz, C. P.; Holt, E. M.; Brock, C. P.; Shriver, D. F. J. Am. Chem. Soc. 1985, 107, 8136. (d) Wang, J.; Sabat, M.; Horwitz, C. P.; Shriver, D. F. Inorg. Chem. 1988, 27, 552.

(3) (a) Chi, Y.; Wu, F.-J.; Liu, B.-J.; Wang, C.-C.; Wang, S.-L. J. Chem. Soc., Chem. Commun. 1989, 873. (b) Chi, Y.; Su, C.-J.; Farrugia, L. J.; Peng, S.-H.; Lee, G.-H. Organometallics 1994, 13, 4167.

(4) (a) Ingham, S. L.; Johnson, B. F. G.; Martin, C. M.; Parker, D. J. Chem. Soc., Chem. Commun. 1995, 159. (b) Blake, A. J.; Dyson, P. J.; Lngham, S. L.; Johnson, B. F. G.; Martin, C. M. Inorg. Chem. Acta. 1995, 240, 29. (d) Kolehmainen, E.; Rissanen, K.; Laihia, K.; Kerzina, Z. A.; Rybinskaya, M. I.; Nieger, M. J. Organomet. Chem. 1996, 524, 219.

(5) (a) Adams, R. D.; Babin, J. E.; Tasi, M. Angew. Chem., Int. Ed.

Engl. 1987, 26, 685. (b) Adams, R. D.; Alexander, M. S.; Arafa, I.; Wu, W. Inorg. Chem. 1991, 30, 4717. (c) Davies, J. E.; Nahar, S.; Raithby, P. R.; Shields, G. P. J. Chem. Soc., Dalton Trans. 1997, 13.

(6) (a) Whitmire, K. H.; Shriver, D. F. J. Am. Chem. Soc. 1981, 103, 6754. (b) Kolis, J. W.; Holt, E. M.; Drezdzon, M.; Whitmire, K. H.; Shriver D. F. J. Am. Chem. Soc. 1982, 104, 6134. (c) Martin, C. M.; Dyson, P. J.; Ingham, S. L.; Johnson, B. F. G.; Blake, A. J. J. Chem. Soc., Dalton Trans. 1995, 2741. (d) Su, C.-J.; Su, P.-C.; Chi, Y.; Peng, S.-M.; Lee, G.-H. J. Am. Chem. Soc. 1996, 118, 3289. complexes $\mathbf{1 b}$ and $\mathbf{1 c}$ were obtained using the hydride complexes $\left[\mathrm{C}_{5} \mathrm{H}_{4}\left(\mathrm{SiMe}_{3}\right)\right] \mathrm{W}(\mathrm{CO})_{3} \mathrm{H}$ and $\left[\mathrm{C}_{5} \mathrm{H}_{4}\left(\mathrm{CHMe}_{2}\right)\right] \mathrm{W}(\mathrm{CO})_{3} \mathrm{H}$, respectively. ${ }^{7}$ All of these products were characterized by IR and ${ }^{1} \mathrm{H}$ and ${ }^{13} \mathrm{C}$ NMR spectroscopies and microanalysis. The X-ray structure of 1a was determined to reveal its identity. ${ }^{7}$

As depicted in Figure 1, the molecule consists of a tetrahedral $\mathrm{WRu}_{3}$ core with the tungsten atom located at the apical position and capped by a $\mathrm{C}_{5} \mathrm{H}_{3}\left(\mathrm{SiMe}_{3}\right)_{2}$ ligand, while the $\mathrm{Ru}$ atoms occupy the basal positions and each possess two terminal $\mathrm{CO}$ ligands. The $\mathrm{W}-\mathrm{Ru}$ distances are nearly equal with distances 2.911(1)-2.917(1) $\AA$, which are longer than the other $\mathrm{Ru}-\mathrm{Ru}$ distances. The $\mathrm{C}_{5} \mathrm{H}_{3}\left(\mathrm{SiMe}_{3}\right)_{2}$ ligand seems to experience some steric congestion, as the $\mathrm{W}-\mathrm{C}\left(\mathrm{SiMe}_{3}\right)$ distances $(2.358(8)-$ $2.368(8) \AA$ ) are relatively longer than the unsubstituted $\mathrm{W}-\mathrm{CH}$ distances $(2.324(7)-2.326(8) \AA)$ of the $\mathrm{C}_{5} \mathrm{H}_{3}\left(\mathrm{SiMe}_{3}\right)_{2}$ ring. The hydride, which was located crystallographically, was found to span the $\mathrm{Ru}_{3}$ basal triangle. Moreover, the $\mathrm{Ru}-\mathrm{Ru}$ edges are each coordinated by a $\mathrm{Ru}(\mathrm{CO})_{3}$ pendant, forming three $\mathrm{WRu}_{3}$ butterfly arrangements, supporting the observed $\mu_{4}-\eta^{2}-\mathrm{CO}$ ligands. The associated metric parameters are similar to those of the tetrametallic butterfly clusters mentioned earlier ${ }^{2,3}$ and other polymetallic clusters bearing the same type of encapsulated $\mu_{4}$-CO ligand. ${ }^{8}$

Interestingly, the cluster framework of $\mathbf{1}$ possesses a virtual $C_{3}$ axis which coincides with the vector linking the $\mathrm{W}$ atom and the hydride ligand. This symmetrical feature is best revealed by the ${ }^{13} \mathrm{C}$ NMR data of $1 \mathbf{a}$, which exhibits five $\mathrm{CO}$ signals at $\delta 288.1\left(J_{\mathrm{WC}}=168 \mathrm{~Hz}\right), 207.6,200.5\left(J_{\mathrm{CH}}=2.4\right.$ $\mathrm{Hz}), 189.6\left(J_{\mathrm{CH}}=12 \mathrm{~Hz}\right)$, and 184.5 with an intensity ratio of 3:3:3:3:6 at room temperature. Thus, the signal at $\delta 288.1$ with the characteristic ${ }^{1} J_{\mathrm{WC}}$ coupling is assigned to the $\mu_{4}-\mathrm{CO}$ ligands. The signals at $\delta 200.5$ and 189.6, which show the ${ }^{2} J_{\mathrm{CH}}$ coupling, are due to the equatorial and the axial $\mathrm{CO}$ ligands associated with the $\mathrm{Ru}$ atoms on the inner metal triangle, while the signals at $\delta 207.6$ and 184.5 with the ratio 3:6 are derived from the axial and the equatorial $\mathrm{CO}$ ligands of the $\mathrm{Ru}(\mathrm{CO})_{3}$ pendants.

Some attempts were made to investigate the $\mu_{4}$-CO reactivity. Thus, treatment of $\mathbf{1 a}-\mathbf{c}$ with $\mathrm{CO}$ in toluene (1 atm, $5 \mathrm{~h}, 110$ $\left.{ }^{\circ} \mathrm{C}\right)$ resulted a slow decomposition. However, as a general example, hydrogenation of 1 a gave a trihydride complex $\left[\mathrm{C}_{5} \mathrm{H}_{3}-\right.$ $\left.\left(\mathrm{SiMe}_{3}\right)_{2}\right] \mathrm{WRu}_{6}(\mu-\mathrm{H})_{3}(\mathrm{CO})_{17}(\mathbf{2})$ in $71 \%$ yield. $^{7}$ The $\mathrm{X}$-ray diffraction study disclosed that it now adopts a double edgebridged trigonal bipyramidal core structure (Figure 2), which is formally derived from the previously mentioned, triple edgebridged tetrahedra by generation of a $\mathrm{W}-\mathrm{Ru}$ bond. Again, the hydride ligands are located, and they span the newly formed $\mathrm{W}-\mathrm{Ru}(1)$ edge, the $\mathrm{Ru}(2)-\mathrm{Ru}(3)$ edge, and the $\mathrm{Ru}(2)-\mathrm{Ru}(4)$ $\mathrm{Ru}(5)$ face, respectively. These assignments are fully consistent with the ${ }^{1} \mathrm{H}$ NMR data which exhibit three signals at $\delta-14.14$ $\left(J_{\mathrm{WH}}=84.8 \mathrm{~Hz}\right),-14.70$, and -20.71 ; the last one is obviously due to the face-bridging hydride because of the large distinction in chemical shift. ${ }^{9}$

More striking behavior of $\mathbf{2}$ was found by VT NMR. For example, the $\mu_{4}$-CO ligands occur at $\delta 292.1$ and 289.2 in the ${ }^{13} \mathrm{C}$ NMR spectrum at $294 \mathrm{~K}$. This observation agrees with

(7) Complete experimental details and characterization data for all new complexes isolated during this work are provided as Supporting Information

(8) (a) Brun, L. P.; Dawkins, G. M.; Green, M.; Miles, A. D.; Orpen, A. G.; Stone, F. G. A. J. Chem. Soc., Chem. Commun. 1982, 926. (b) Johnson, B. F. G.; Lewis, J.; McPartlin, M.; Pearsall, M.-A.; Sironi, A. J. Chem. Soc., Chem. Commun. 1984, 1089. (c) Gibson, C. P.; Dahl, L. F. Organometallics 1988, 7, 535. (d) Chi, Y.; Chuang, S.-H.; Liu, L.-K.; Wen, Y.-S. Organometallics 1991, 10, 2485. (e) Adams, R. D. Li, Z.; Lii, J.-C.; Wu, W. Organometallics 1992, 11, 4001. (f) Corrigan, J. F.; Doherty, S.; Taylor, N. J.; Carty, A. J. Organometallics 1993, 12, 993. (g) Wang, J.-C.; Lin, R.-C.; Chi, Y.; Peng, S.-M.; Lee, G.-H. Organometallics 1993, 12 4061. (h) Su, P.-C.; Chi, Y.; Su, C.-J.; Peng, S.-M.; Lee, G.-H. Organometallics 1997, 16, 1870.

(9) Chao, W.-J.; Chi, Y.; Way, C.-J.; Mavunkal, I. J.; Wang, S.-L.; Liao, F.-L.; Farrugia, L. J. Organometallics 1997, 16, 3523. 


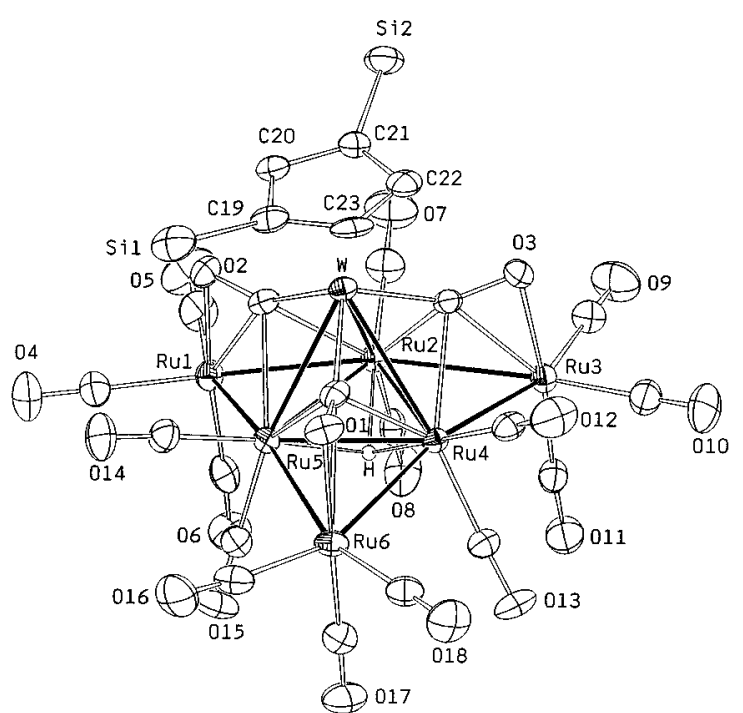

Figure 1. Molecular structure of $\mathbf{1 a}$ and the atomic numbering scheme; the methyl groups of the trimethylsilyl substituents were omitted for clarity. Selected bond lengths $(\AA): \mathrm{W}-\mathrm{Ru}(2)=2.917(1), \mathrm{W}-\mathrm{Ru}(4)$ $=2.913(1), \mathrm{W}-\mathrm{Ru}(5)=2.911(1), \mathrm{Ru}(2)-\mathrm{Ru}(4)=2.801(1), \mathrm{Ru}(2)-$ $\mathrm{Ru}(5)=2.799(1), \mathrm{Ru}(4)-\mathrm{Ru}(5)=2.815(1), \mathrm{Ru}(1)-\mathrm{Ru}(2)=2.811(1)$, $\mathrm{Ru}(1)-\mathrm{Ru}(5)=2.828(1), \mathrm{Ru}(2)-\mathrm{Ru}(3)=2.820(1), \mathrm{Ru}(3)-\mathrm{Ru}(4)=$ 2.804(1), $\mathrm{Ru}(4)-\mathrm{Ru}(6)=2.805(1), \mathrm{Ru}(5)-\mathrm{Ru}(6)=2.820(1)$.

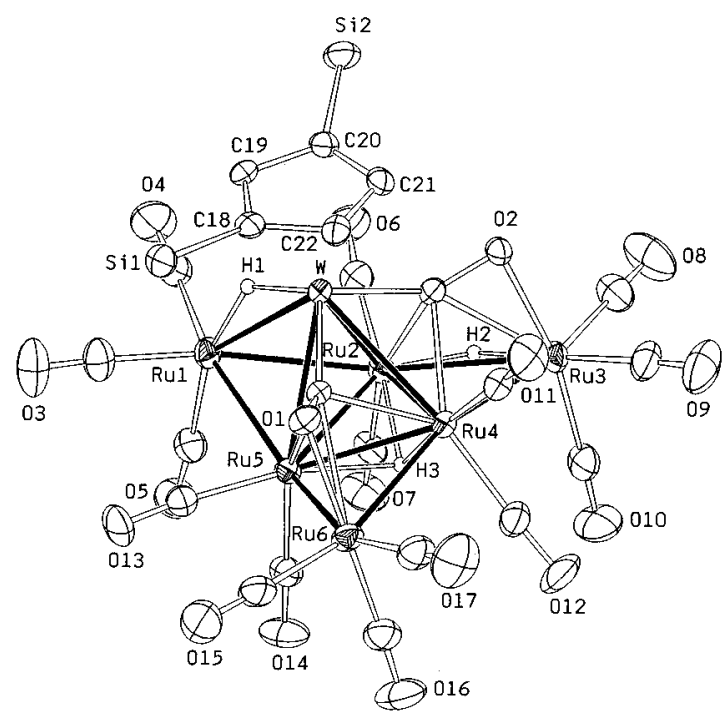

Figure 2. Molecular structure of $\mathbf{2}$ and the atomic numbering scheme; the methyl groups of the trimethylsilyl substituents were omitted for clarity. Selected bond lengths $(\AA): \mathrm{W}-\mathrm{Ru}(1)=2.996(1), \mathrm{W}-\mathrm{Ru}(2)$ $=2.882(1), \mathrm{W}-\mathrm{Ru}(4)=2.922(1), \mathrm{W}-\mathrm{Ru}(5)=2.986(1), \mathrm{Ru}(2)-\mathrm{Ru}(4)$ $=2.838(1), \mathrm{Ru}(2)-\mathrm{Ru}(5)=2.824(1), \mathrm{Ru}(4)-\mathrm{Ru}(5)=2.740(1)$, $\mathrm{Ru}(1)-\mathrm{Ru}(2)=2.832(1), \mathrm{Ru}(1)-\mathrm{Ru}(5)=2.741(1), \operatorname{Ru}(2)-\mathrm{Ru}(3)=$ 2.888(1), $\operatorname{Ru}(3)-\mathrm{Ru}(4)=2.827(1), \mathrm{Ru}(4)-\mathrm{Ru}(6)=2.851(1), \mathrm{Ru}(5)-$ $\mathrm{Ru}(6)=2.727(1)$.

the asymmetric nature of the cluster skeleton indicated by the $\mathrm{X}$-ray analysis. Upon raising of the temperature to $325 \mathrm{~K}$, these CO signals coalesce to form a broad signal centered at $\delta 291.1$. In addition, two of the three distinct olefinic hydrogen of the $\mathrm{C}_{5} \mathrm{H}_{3}\left(\mathrm{SiMe}_{3}\right)_{2}$ substituent at $\delta 5.23$ and 4.85 in its ${ }^{1} \mathrm{H}$ NMR spectrum at $294 \mathrm{~K}$ merge to form a broad signal at $\delta 5.06$ at $325 \mathrm{~K}$. These temperature-dependent behaviors are best interpreted in terms of the hydride hopping between the $\mathrm{Ru}-$ (2) $-\mathrm{Ru}(3)$ edge and the $\mathrm{Ru}(5)-\mathrm{Ru}(6)$ edge of the $\mathrm{Ru}_{6}$ basal plane, forming a dynamic plane of mirror symmetry. Interestingly, the scrambling of the $\mathrm{Ru}-\mathrm{H}-\mathrm{Ru}$ hydride and the facebridging hydride was also noted under the same conditions, suggesting that the proposed hydride hopping is relayed by the face-bridging hydride ligand (Scheme 1). Consistent with this
Scheme 1

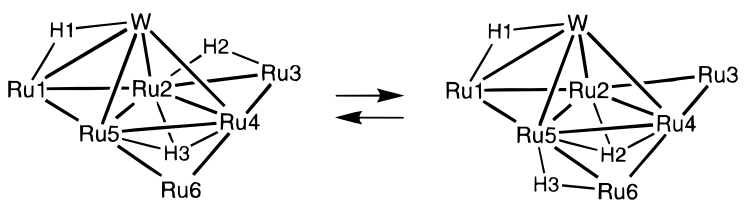

observation, the signals at $\delta-14.70$ and -20.71 are broaden extensively on warming to $303 \mathrm{~K}$, suggesting the presence of pairwise exchange between these sites. The nonselective scrambling of all hydride ligands becomes possible only at the higher temperature, as the signal at $\delta-14.14$, due to the third $\mathrm{W}-\mathrm{H}-\mathrm{Ru}$ hydride ligand, has turned much broader upon warming to $333 \mathrm{~K}$, confirming the existence of such a higher energy process.

In summary, this paper reports the first example of transition metal clusters bearing three $\mu_{4}-\mathrm{CO}$ ligands. Two observations deserve additional comments. First, the formation of $\mathrm{WRu}_{6}$ clusters $\mathbf{1 a}-\mathbf{c}$ is in sharp contrast to that of the condensation reactions using $\mathrm{CpW}(\mathrm{CO})_{3} \mathrm{H}$ or $\left(\mathrm{C}_{5} \mathrm{Me}_{5}\right) \mathrm{W}(\mathrm{CO})_{3} \mathrm{H}$, which gave only the tetrametallic counterparts $\mathrm{LWRu}_{3}(\mu-\mathrm{H})(\mathrm{CO})_{12}(\mathrm{~L}=\mathrm{Cp}$ and $\left.\mathrm{C}_{5} \mathrm{Me}_{5}\right){ }^{3}$ The key factors leading to the formation of the $\mathrm{WRu}_{6}$ compounds can be deduced by comparing the spectroscopic data of the substituted group 6 hydride complexes ${ }^{7}$ with those of their parent $\mathrm{CpW}(\mathrm{CO})_{3} \mathrm{H}$. It suggests that the electronic effect imposed by the trimethylsilyl or isopropyl groups is minimal because the positions of their IR $v(\mathrm{CO})$ absorptions and the ${ }^{1} \mathrm{H}$ NMR chemical shifts for hydrides are very similar. As a result, these cyclopentadienyl groups seem to exert their influence through steric interaction exclusively. ${ }^{10}$ However, this interligand repulsion is very subtle and can be depressed by removing of a CO ligand through ligand displacement. ${ }^{11}$ Thus, complex $\mathbf{2}$ is available through hydrogenation of 1a, demonstrating the elevation of such a steric interaction.

Second, the formation of the smaller, tetrametallic complex $\mathrm{LWRu}_{3}(\mu-\mathrm{H})(\mathrm{CO})_{12}$ as the potential intermediate is also ruled out by the unsuccessful coupling experiment using $\left[\mathrm{C}_{5} \mathrm{H}_{4-}\right.$ $\left.\left(\mathrm{CHMe}_{2}\right)\right] \mathrm{WRu}_{3}(\mu-\mathrm{H})(\mathrm{CO})_{12}$ and $\mathrm{Ru}_{3}(\mathrm{CO})_{12}$ as reagents; the former was prepared from condensation of $\mathrm{Ru}_{3}(\mathrm{CO})_{12}$ and $\left[\left\{\mathrm{C}_{5} \mathrm{H}_{4}\left(\mathrm{CHMe}_{2}\right)\right\} \mathrm{W}(\mathrm{CO})_{3}\right] \mathrm{Na}$ in THF, followed by acidification. ${ }^{12}$ Thus, the the formation of $\mathbf{1}$ occurs not via the expected step-by-step cluster building reaction

$$
\begin{array}{r}
{[\mathrm{W} \text { complex }]+\mathrm{Ru}_{3}(\mathrm{CO})_{12} \rightarrow\left[\mathrm{WRu}_{3} \text { intermediate }\right]} \\
\rightarrow
\end{array} \rightarrow
$$

but via an unknown trimolecular coupling involving one tungsten hydride complex and two $\mathrm{Ru}_{3}(\mathrm{CO})_{12}$ molecules simultaneously.

Acknowledgment. We are grateful to the National Science Council of the Republic of China for financial support (Grant No. NSC 862113-M007-035).

Supporting Information Available: Text describing experimental details and spectroscopic data for $\mathbf{1 a}-\mathbf{c}$ and $\mathbf{2}$ and tables of bond distances, atomic coordinates, and anisotropic thermal parameters for 1a and 2 (17 pages). See any current masthead page for ordering and Internet access instructions.

\section{JA9720927}

(10) (a) Lappert, M. F.; Pickett, C. J.; Riley, P. I.; Yarrow, P. I. W. J. Chem. Soc., Dalton Trans. 1981, 805. (b) Antinolo, A.; de Ilarduya, J. M.; Otero, A.; Royo, P.; Lanfredi, A. M. M.; Tiropicchio, A. J. Chem. Soc. Dalton Trans. 1988, 2685. (c) Okuda, J. Top. Curr. Chem. 1992, 160, 97.

(11) (a) Churchill, M. R.; Hollander, F. J.; Shapley, J. R.; Foose, D. S. J. Chem. Soc., Chem. Commun. 1978, 534. (b) Chi, Y.; Cheng, C.-Y.; Wang, S.-L. J. Organomet. Chem. 1989, 378, 45.

(12) (a) Cazanoue, M.; Lugan, N.; Bonnet, J.-J.; Mathieu, R. Organometallics 1988, 7, 2480. (b) Su, C.-J.; Chi, Y.; Peng, S.-M.; Lee, G.-H Organometallics 1995, 14, 4286. 